\title{
A study to evaluate accuracy of gestational age, comparing conventional method against duration of intermenstrual interval consideration
}

\author{
Pawanpreet Kaur*, Deepak A. Desai, Aartee Taraiya
}

\begin{abstract}
Department of Obstetrics \& Gynaecology, Dhiraj General Hospital, S.B.K.S Medical Institute \& Research Centre, Pipariya, Waghodia, Vadodara-391760, Gujarat, India
\end{abstract}

Received: 24 June 2015

Revised: 20 August 2015

Accepted: 21 August 2015

\author{
*Correspondence: \\ Dr. Pawanpreet Kaur, \\ E-mail: pavs_candy@yahoo.co.in
}

Copyright: () the author(s), publisher and licensee Medip Academy. This is an open-access article distributed under the terms of the Creative Commons Attribution Non-Commercial License, which permits unrestricted non-commercial use, distribution, and reproduction in any medium, provided the original work is properly cited.

\begin{abstract}
Background: Most methods of calculating gestational length are based upon 28 day cycle. If a woman has a cycle which is significantly shorter than 28 days and she delivers before her due date calculated by her LMP, this arises an anticipation of a premature baby, but the fetus is mature by all criteria of maturity assessment. Dr. Modi (Text Book of Medical Jurisprudence) stated, 'duration of pregnancy in homo homosapiens is 10 times the inter-menstrual interval'. Keeping this in mind we undertook this study.

Methods: The study was done for a duration of 1 year. The gestational age of patients was calculated from the routine Naegele's formula and inter-menstrual interval. The maturity of neonate was assessed by using Ballard's score. This data was co-related for further evaluation.

Results: Although 39 (19.5\%) neonates were expected to be preterm, 24 (12\%) actually turned out to be preterm according to Ballard's score. Rest 15 neonates, premature by Naegele's formula, should be in "premature" group, turned out to be well developed, by Ballard's score, almost $37.5 \%$ of early delivery group, (significant at $\mathrm{P}<0.05$ )

Conclusions: This showed that the baby attained maturity at a lesser gestational age which corresponded to 10 times the inter-menstrual interval.
\end{abstract}

Keywords: Intermenstrual interval, Ballard's score, Preterm

\section{INTRODUCTION}

We have it ingrained in our heads throughout our entire adult lives-pregnancy is 40 weeks. The "due date" we are given at that first prenatal visit is based upon that 40 weeks, and we look forward to it with great anticipation.

When we are still pregnant after that magical date, we call ourselves "overdue" and the days seem to drag on like years. The problem with this belief about the 40 week EDD is that it is not based in fact. It is one of many pregnancy and childbirth myths which has wormed its way into the standard of practice over the years- something that is still believed because "that's the way it's always been done".

Average duration of pregnancy, is ordinarily the period that elapses between the conception and delivery. Commonly, the date of last menstrual period is considered, to estimate the average duration of pregnancy, and to calculate the approximate time for expected date of delivery. As per Naegele's formula, nine calendar months and seven days are added to the last menstrual period date. Alternatively, 10 lunar months or 280 days or 40 weeks can be used to calculate the approximate expected date. 
The 40 week due date is based upon Naegele's Rule. The formula was publicized around 1812 by German obstetrician Franz Naegele and since has become the accepted norm for calculating the due date. There is one glaring flaw in Naegele's rule. Strictly speaking, a lunar (or synodic - from new moon to new moon) month is actually 29.53 days, which makes 10 lunar months roughly 295 days, a full 15 days longer than the 280 days gestation we've been lead to believe is average. In fact, if left alone, $50-80 \%$ of mothers will gestate beyond 40 weeks.

Aside from the gross miscalculation of the lunar due date, there is another common problem associated with formulating a woman's EDD: most methods of calculating gestational length are based upon a 28 day cycle. Not all women have a 28 day cycle; some are longer, some are shorter, and even those with a 28 day cycle do not always ovulate right on day 14 .

If a woman has a cycle which is significantly shorter than 28 days and she delivers before her due date, as calculated according to her LMP (last menstrual period), this arises an anticipation of a premature baby, but the fetus delivered is mature by all criteria of maturity assessment done by Ballard's score.

Question that comes to mind is - Why so? and it remains unanswered many times.

The answer was found in Text Book of Medical Jurisprudence by Dr. Modi, wherein he has stated, 'duration of pregnancy in homo homosapiens is 10 times the inter-menstrual interval'. This statement looks at par with Naegele's statement that pregnancy duration is 10 lunar months.

The Ballard maturational assessment, Ballard score, or Ballard scale is a commonly used technique of gestational age assessment. It assigns a score to various criteria, the sum of all of which is then extrapolated to the gestational age of the baby. These criteria are divided into physical and neurological criteria. This scoring allows for the estimation of age in the range of 26 weeks-44 weeks. The new Ballard score is an extension of the above to include extremely pre-term babies i.e. up to 20 weeks. The scoring relies on the intra-uterine changes that the fetus undergoes during its maturation. Whereas the neurological criteria depend mainly upon muscle tone, the physical ones rely on anatomical changes.

$>$ Sidney H. Weddy described a case in which a woman, aged 30 years, gave birth to a full-time daughter after a gestation of 210 days. The child cried lustily at birth, had a crop of hair, was well coated with vernix caseosa, measured 20 inches in length and weight seven pounds. The finger and toenails were fully developed and the child sucked vigorously on being put to the breast. ${ }^{2}$
J. K. Mohanty of Angul of the district of Cuttack, reported the case of a Hindu woman aged 36 years, who delivered a male child after a period of gestation of 315 days, reckoned from the first day of her last menstrual period, and nearly 300 days calculated from probably day of ovulation or fertilization. The child was 22 inches long and weighed 9 pounds 6 ounces. The centers of ossification were visible in the upper epiphysis of the tibia and humerus in addition to that in the lower epiphysis of the femur. ${ }^{3}$

$>$ Dr. Phillips reported the case of a young unmarried girl in whom gestation lasted 324 days after the cessation of her menstruation and 311 days after the date of coitus. ${ }^{4}$

J. K. Walker, studied that a healthy male child was delivered on the $315^{\text {th }}$ day after the last date of intercourse. ${ }^{5}$

Tausch Manatschrift observed that a primiparous, 27 years old, was delivered of a well-developed girl on the $343^{\text {rd }}$ day after her last menstrual period. The girl considerably larger than a normal child was $50 \mathrm{~cm}$ long and weighted $5000 \mathrm{~g}^{6}$

With this idea in mind, to determine the effectively actual duration of pregnancy with regard to fetal maturity, when the patient delivers earlier, we have undertaken this study.

\section{METHODS}

The study was done in Dhiraj General Hospital in Obstetrics and Gynecology department for a duration of 1 year. It was prospective type of study comprising of patients, who were booked cases and delivered at Dhiraj hospital.

The gestational age of these patients was calculated from the routine Naegele's formula as per their last menstrual period. Also, their gestational age was estimated based on their inter-menstrual period.

The gestational age when she delivered, was observed. The neonate was examined for the exact gestational age on the day of delivery. And their maturity was assessed by the pediatrician using the Ballard's score. This available data was co-related for further evaluation.

\section{Aims of study}

1. To find out the relationship between the intermenstrual period and the gestational age.

2. To evaluate the fetal maturity according to gestational age calculated by inter menstrual interval. 


\section{Calculation of expected date of delivery}

\section{A) According to Neagle's formula:}

By adding 9 calendar months and 7 days to the first day of last normal (28 day cycle) period.

\section{B) According to inter-menstrual interval:}

10 times the inter-menstrual interval.

C) Calculation of fetal maturity after delivery by Ballard's score:

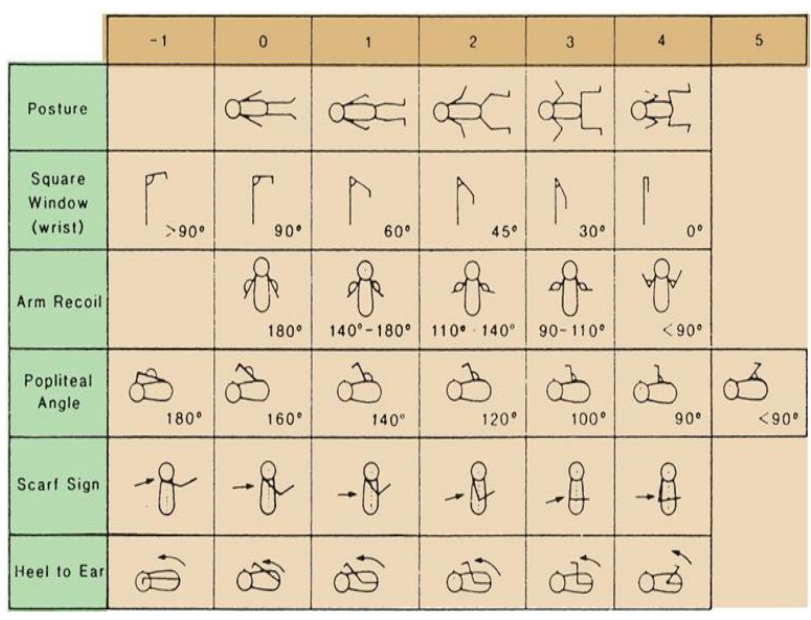

Figure 1: Neuromuscular maturity.

\begin{tabular}{|c|c|c|c|c|c|c|c|c|}
\hline & -1 & 0 & 1 & 2 & 3 & 4 & & \\
\hline Skin & $\begin{array}{c}\text { sticky } \\
\text { friable } \\
\text { transparent }\end{array}$ & $\begin{array}{c}\text { gelatinous } \\
\text { red, } \\
\text { translucent }\end{array}$ & $\begin{array}{l}\text { smooth pink, } \\
\text { visible veins }\end{array}$ & $\begin{array}{c}\text { superficial } \\
\text { peeling } \\
\text { \&lor rash. } \\
\text { few veins }\end{array}$ & $\begin{array}{l}\text { cracking } \\
\text { pale areas } \\
\text { rare veins }\end{array}$ & $\begin{array}{l}\text { parchment } \\
\text { deep } \\
\text { cracking } \\
\text { no vessels }\end{array}$ & \multicolumn{2}{|c|}{$\begin{array}{l}\text { leathery cracked } \\
\text { wrinkled }\end{array}$} \\
\hline Lanugo & none & sparse & abundant & thinning & bald areas & $\begin{array}{c}\text { mostly } \\
\text { bald }\end{array}$ & \multirow{2}{*}{\multicolumn{2}{|c|}{$\begin{array}{c}\text { Maturity } \\
\text { Rating }\end{array}$}} \\
\hline \multirow{3}{*}{$\begin{array}{l}\text { Plantar } \\
\text { Surface }\end{array}$} & \multirow{3}{*}{$\begin{array}{c}\text { heel-toe } \\
40-50 \mathrm{~mm}:-1 \\
<40 \mathrm{~mm}:-2\end{array}$} & \multirow{3}{*}{$\begin{array}{c}>50 \mathrm{~mm} \\
\text { no } \\
\text { crease }\end{array}$} & \multirow{3}{*}{$\begin{array}{l}\text { faint } \\
\text { red marks }\end{array}$} & \multirow{3}{*}{$\begin{array}{c}\text { anterior } \\
\text { transverse } \\
\text { crease only } \\
\end{array}$} & \multirow{3}{*}{$\begin{array}{l}\text { creases } \\
\text { ant. } 2 / 3\end{array}$} & \multirow{3}{*}{$\begin{array}{c}\text { creases } \\
\text { over entire } \\
\text { sole }\end{array}$} & & \\
\hline & & & & & & & Score & weeks \\
\hline & & & & & & & \begin{tabular}{|l|}
-10 \\
\end{tabular} & 20 \\
\hline \multirow{3}{*}{ Breast } & \multirow{3}{*}{ imperceptible } & \multirow{3}{*}{$\begin{array}{c}\text { barely } \\
\text { perceptible }\end{array}$} & \multirow{3}{*}{$\begin{array}{l}\text { flat areola } \\
\text { no bud }\end{array}$} & \multirow{3}{*}{$\begin{array}{c}\text { stippled } \\
\text { areola } \\
1-2 \mathrm{~mm} \text { bud }\end{array}$} & \multirow{3}{*}{\begin{tabular}{|c|} 
raised \\
areola \\
$3-4 \mathrm{~mm}$ bud
\end{tabular}} & \multirow{3}{*}{$\begin{array}{l}\text { full areola } \\
5-10 \mathrm{~mm} \\
\text { bud }\end{array}$} & -5 & 22 \\
\hline & & & & & & & & \\
\hline & & & & & & & 5 & 26 \\
\hline \multirow[b]{2}{*}{ Eye/Ear } & \multirow{3}{*}{$\begin{array}{l}\text { lids fused } \\
\text { loosely: }-1 \\
\text { tightly: }-2 \\
\end{array}$} & \multirow{3}{*}{\begin{tabular}{|c|} 
lids open \\
pinna flat \\
stays folded
\end{tabular}} & \multirow{3}{*}{$\begin{array}{l}\text { sl. Curved } \\
\text { pinna; soft; } \\
\text { slow recoil }\end{array}$} & \multirow{3}{*}{\begin{tabular}{|c|} 
well-curved \\
pinna; soft but \\
ready recoil \\
\end{tabular}} & \multirow{3}{*}{\begin{tabular}{|c|} 
formed \& \\
firm instant \\
recoil
\end{tabular}} & \multirow{3}{*}{$\begin{array}{c}\text { thick } \\
\text { cartilage } \\
\text { ear stiff }\end{array}$} & 10 & 28 \\
\hline & & & & & & & 15 & 30 \\
\hline \multirow{3}{*}{$\begin{array}{c}\text { Genitals } \\
\text { male }\end{array}$} & & & & & & & 20 & 32 \\
\hline & \multirow{2}{*}{$\begin{array}{l}\text { scrotum } \\
\text { flat, } \\
\text { smooth }\end{array}$} & \multirow{2}{*}{\begin{tabular}{c|} 
scrotum \\
empty faint \\
rugae
\end{tabular}} & \multirow{2}{*}{$\begin{array}{l}\text { testes in upper } \\
\text { canal rare rugae }\end{array}$} & \multirow{2}{*}{$\begin{array}{l}\text { testes descend- } \\
\text { ing few rugae }\end{array}$} & \multirow{2}{*}{$\begin{array}{l}\text { testes down } \\
\text { good rugae }\end{array}$} & \multirow{2}{*}{$\begin{array}{c}\text { testes } \\
\text { pendulous } \\
\text { deep rugae } \\
\end{array}$} & 25 & \\
\hline & & & & & & & 30 & 36 \\
\hline \multirow{3}{*}{$\begin{array}{l}\text { Genitals } \\
\text { female }\end{array}$} & \multirow{3}{*}{$\begin{array}{l}\text { clitoris promi- } \\
\text { nent labia flat }\end{array}$} & \multirow{3}{*}{\begin{tabular}{|c|} 
prominent \\
clitoris small \\
labia minora
\end{tabular}} & \multirow{3}{*}{$\begin{array}{c}\text { prominent } \\
\text { clitoris enlarg- } \\
\text { ing minora }\end{array}$} & \multirow{3}{*}{$\begin{array}{c}\text { majora \& } \\
\text { minora equally } \\
\text { prominent }\end{array}$} & \multirow{3}{*}{$\begin{array}{l}\text { majora large } \\
\text { minora small }\end{array}$} & & 40 & 40 \\
\hline & & & & & & & 45 & 42 \\
\hline & & & & & & & 5 & 44 \\
\hline
\end{tabular}

Figure 2: Physical maturity.

\section{Inclusion criteria}

1. All antenatal patients were booked and delivered at Dhiraj hospital.

2. Patients who delivered after 28 weeks of gestation.

3. Patients who had regular menstrual cycles and were sure of their last menstrual dates.

\section{Exclusion criteria}

1. Patients who had delivered before 28 weeks of gestation.

2. Patients who had irregular menstrual cycle and were not sure of their last menstrual dates.

3. Patients who had a menstrual cycle longer than 32 days and shorter than 22 days.

\section{RESULTS}

Amongst 200 pregnant patients, maximum were under the age group of 20-25 years i.e. 108 (54\%) (Table 1).

Table 1: Distribution according to age group.

\begin{tabular}{|lll|}
\hline $\begin{array}{l}\text { Age } \\
\text { (years) }\end{array}$ & $\begin{array}{l}\text { Number of } \\
\text { patients }\end{array}$ & Percentage \\
\hline $18-20$ & 38 & $19 \%$ \\
\hline $20-25$ & 108 & $54 \%$ \\
\hline$>26$ & 54 & $27 \%$ \\
\hline
\end{tabular}

Amongst 200 patients, 106 (94\%) were primigravida and $94(47 \%)$ were multigravida (Table 2$)$.

Table 2: Distribution according to parity.

\begin{tabular}{|lll|}
\hline Parity & $\begin{array}{l}\text { Number of } \\
\text { patients }\end{array}$ & Percentage \\
\hline Primigravida & 106 & $53 \%$ \\
\hline Multigravida & 94 & $47 \%$ \\
\hline
\end{tabular}

Table 3A: Distribution of number of patients according to last menstrual period (LMP) $(n=200)$.

\begin{tabular}{|lll|}
\hline & $\begin{array}{l}\text { Number of } \\
\text { patients }\end{array}$ & Percentage \\
\hline Full term & 166 & $83 \%$ \\
\hline Pre term & 34 & $17 \%$ \\
\hline
\end{tabular}

Table 3B: Distribution of number of patients according to inter-menstrual period (IMP) $(n=200)$.

\begin{tabular}{|lll|}
\hline & $\begin{array}{l}\text { Number of } \\
\text { patients }\end{array}$ & Percentage \\
\hline Full term & 161 & $80.5 \%$ \\
\hline Pre term & 39 & $19.5 \%$ \\
\hline
\end{tabular}

Table 3C: Distribution of number of patients according to USG $(n=200)$.

\begin{tabular}{|lll|}
\hline & $\begin{array}{l}\text { Number of } \\
\text { patients }\end{array}$ & Percentage \\
\hline Full term & 157 & $78.5 \%$ \\
\hline Pre term & 43 & $21.5 \%$ \\
\hline
\end{tabular}


The number of expected pre-term neonates according to maternal gestational age: From LMP were: 34 (17\%); IMP where: 39 (19.5\%); USG where: 43 (21.5\%). As the duration of pregnancy according to IMP is less, the preterm outcome seems to be more.

After Ballard's scoring of the neonates, 24 (12\%) were found to be pre-term and full term $176(88 \%)$ (Table 4).
Table 4: Distribution of number of patients according to Ballard's score, in terms of maturity $(n=200)$.

\begin{tabular}{|lll|}
\hline & $\begin{array}{l}\text { Number of } \\
\text { patients }\end{array}$ & Percentage \\
\hline Full term & 176 & $88 \%$ \\
\hline Pre term & 24 & $12 \%$ \\
\hline
\end{tabular}

Table 5: Distribution of number of patients according to gestational age groups and average duration of menstrual cycle.

\begin{tabular}{|llllll|}
$\begin{array}{l}\text { Average } \\
\text { duration of } \\
\text { menstrual } \\
\text { cycle (Days) }\end{array}$ & $\begin{array}{l}\text { Average } \\
\text { gestational } \\
\text { age } \\
\text { (Weeks) }\end{array}$ & $\begin{array}{l}\text { Expected } \\
\text { pre-term or } \\
\text { full-term }\end{array}$ & $\begin{array}{l}\text { Number of } \\
\text { patients } \\
\text { according } \\
\text { to IMIP } \\
(\mathrm{n}=200)\end{array}$ & $\begin{array}{l}\text { Number of } \\
\text { patients } \\
\text { according } \\
\text { to USG } \\
(\mathrm{n}=200)\end{array}$ & $\begin{array}{l}\text { Number of } \\
\text { patients } \\
\text { according } \\
\text { to LMP } \\
(\mathrm{n}=200)\end{array}$ \\
\hline $22-24$ & $32-34$ & Pre-term & $13(6.5 \%)$ & $15(7.5 \%)$ & $8(4 \%)$ \\
\hline $25-27$ & $35-37$ & Pre-term & $26(13 \%)$ & $28(14 \%)$ & $26(13 \%)$ \\
\hline $28-30$ & $38-42$ & Full-term & $161(80.5 \%)$ & $157(78.5 \%)$ & $166(83 \%)$ \\
\hline
\end{tabular}

Average duration of menstrual cycle was taken and the corresponding gestational ages were determined according to inter-menstrual period multiplied by 10 , it turned out to be that, the women with menstrual cycle of 25 to 27 days have a term gestation at 35 to 37 weeks. We had 26 such patients i.e. $13 \%$ of our sample size $(\mathrm{n}=200)$ (Table 5).

Although $39(19.5 \%)$ neonates were expected to be preterm, only $24(12 \%)$ actually turned out to be preterm according to Ballard's Score. This shows that the baby had attained maturity at a lesser gestational age which corresponds to the inter-menstrual period of the women (Table 6).

Although 34 (17\%) neonates were expected to be preterm by LMP, only $24(12 \%)$ actually turned out to be preterm according to Ballard's score (Table 7).

Although $43(21.5 \%)$ neonates were expected to be preterm by USG, only $24(12 \%)$ actually turned out to be preterm according to Ballard's score (Table 8).

Table 6: Comparison of full term $\&$ pre-term neonates according to Ballard's score with intermenstrual interval.

\begin{tabular}{|lllll|}
\multicolumn{4}{c}{ Ballard's score } & IMP \\
& Full-term & Pre-term & Full-term & Pre-term \\
\hline $\begin{array}{l}\text { No. of } \\
\text { patients }\end{array}$ & 176 & 24 & 161 & 39 \\
\hline$\%$ & $88 \%$ & $12 \%$ & $80.5 \%$ & $19.5 \%$ \\
\hline
\end{tabular}

The $\mathrm{P}$ value is 0.039503 . This result is significant at $\mathrm{P}<0.05$.
Table 7: Comparison of full term \& pre-term neonates according to Ballard's score with last menstrual period.

\begin{tabular}{|lllll|}
\multicolumn{4}{c}{ Ballard's score } & LMP \\
& Full-term & Pre-term & Full-term & Pre-term \\
\hline $\begin{array}{l}\text { No. of } \\
\text { patients }\end{array}$ & 176 & 24 & 166 & 34 \\
\hline$\%$ & $88 \%$ & $12 \%$ & $83 \%$ & $17 \%$ \\
\hline
\end{tabular}

Table 8: Comparison of full term \& pre-term neonates according to Ballard's score with USG.

\begin{tabular}{|lllll|}
\multicolumn{4}{c}{ Ballard's score } & LMIP \\
& Full-term & Pre-term & Full-term & Pre-term \\
\hline $\begin{array}{l}\text { No. of } \\
\text { patients }\end{array}$ & 176 & 24 & 157 & 43 \\
\hline$\%$ & $88 \%$ & $12 \%$ & $78.5 \%$ & $21.5 \%$ \\
\hline
\end{tabular}

\section{DISCUSSION}

With all the data available, we observe many times, that a woman delivers earlier than her due date, as determined by her E.D.D., and fetus by all criteria of maturity assessment is a well-developed one, and not premature.

As stated in Text Book of Medical Jurisprudence by Dr. Modi, that 'duration of pregnancy in homo homosapiens is 10 times the inter-menstrual interval'. ${ }^{1}$ This statement looks at par with Naegele's statement that pregnancy duration is 10 lunar months.

The snag of this statement is that it does not explain the achievement of maturity, even when, patient has delivered early by more than 2 to 3 weeks, ( 7 days 
difference on either side of due date, is an acceptable variant).

One more point of consideration to be borne in mind is, 10 times inter-menstrual interval being the period of pregnancy, is applicable to a menstrual cycle that lasts 28 to 30 days or lesser. Cycles of duration shorter than 22 days were not included in this study, as this short length of cycles is very rare, and they usually are patients of subfertility.

Moreover, delivery before 220 days cannot be construed as a mature delivery by any count.

Cycles of longer duration than 30 days cannot be encompassed in this statement because, pregnancy of more than 300 days is a rarity in human species.

\section{CONCLUSION}

Average duration of menstrual cycle was taken and the corresponding gestational ages were determined by 10 times multiplying the inter-menstrual interval.

It turned out to be that, the women with menstrual cycle of 25 to 27 days had a term gestation at around 35 to 37 weeks. We had 26 such patients i.e.13\% of our sample size $(n=200)$.

The patients with menstrual cycle of 22 to 24 days had a term gestation at around 32 to 34 weeks. We had 13 such patients i.e. $6.5 \%$ of our sample size $(n=200)$.

So, although $39(19.5 \%)$ neonates were expected to be preterm, only $24(12 \%)$ actually turned out to be preterm according to Ballard's score. Remaining 15 neonates, premature by conventional method of calculation, should be in "premature" group, turned out to be well developed, by Ballard's score, almost $37.5 \%$ of early delivery group. This showed that the baby had attained maturity at a lesser gestational age which corresponded to 10 times the inter-menstrual interval.

The $\mathrm{P}$ value comes out to be 0.039503 . This result is significant at $\mathrm{P}<0.05$

So, the quotation in the Text Book of Medical Jurisprudence by Dr. Modi, wherein he has stated, 'duration of pregnancy in homo homosapiens is 10 times the inter-menstrual interval', is quiet helpful in abolishing the stigma of an anticipated pre-term delivery in minds of an obstetrician regarding a patient with a shorter intermenstrual interval.

Funding: No funding sources

Conflict of interest: None declared

Ethical approval: The study was approved by the institutional ethics committee

\section{REFERENCES}

1. Mathiharan K, Amrit K. Patnaik. Legitimacy and legal aspects of marriage annulment. In: K. Mathiharan, Amrit K. Patnaik, eds. Modi's Text Book of Medical Jurisprudence and Toxicology. 23rd ed. New Delhi: Lexis Nexis; 2006: 967.

2. Weddy SH. The duration of pregnancy. Br Med J. 1928;1(3497):75.

3. Mohanty JK. Case report of a Hindu women. IMG. 1944;1:23.

4. Philip. Case report of a young unmarried girl. Lancet. 1900;1:94.

5. Walker JF. A long pregnancy. Br Med J. 1939 Jun; $1: 1155$.

6. Tausch. Manatschrift f Geburtshulfc v Gynakologie Berlin. JAMA. 1933;137:704.

Cite this article as: Kaur P, Desai DA, Taraiya A. A study to evaluate accuracy of gestational age, comparing conventional method against duration of intermenstrual interval consideration. Int J Reprod Contracept Obstet Gynecol 2015;4:1291-5. 